[Review Paper]

\title{
Metal Oxide Nanosheets Synthesized by Bottom-up Approach: Applications to Catalyst and Separation Membranes
}

\author{
Keizo NAKAGAWA* \\ Center for Membrane and Film Technology, Graduate School of Science, Technology and Innovation, Kobe University,
} 1-1 Rokkodai, Nada-ku, Kobe 657-8501, JAPAN

(Received October 15, 2018)

\begin{abstract}
Two-dimensional (2D) transition metal oxide nanosheets have useful characteristics such as high surface areas, and defined and controllable surface acidity, with potential for applications in solid acid catalysts and photocatalysts. The most common synthesis method to obtain 2D metal oxide nanosheets is the "exfoliation method" from the corresponding bulk layered oxide by the top-down approach. However, fragmentation and re-aggregation of nanosheets are some of the problems. In addition, this method requires calcination processes for the synthesis of layered compounds at high temperature and prolonged exfoliation treatment of the $2 \mathrm{D}$ crystal layer. In this study, layered titanate nanosheets and single layer niobate nanosheets were formed by the bottom-up approach utilizing hydrolysis and condensation of metal alkoxides in the presence of surfactants. Formation processes of the metal oxide nanosheets and effects of surface modification by the surfactants on their properties were studied. In addition, these nanosheets were evaluated for photocatalytic reactions such as photodegradation of organic dyes and hydrogen evolution from water decomposition. Composites of niobate nanosheets with other types of 2D nanosheets (graphene oxide and $\mathrm{MoS}_{2}$ ) achieved effective photocatalytic activities. Furthermore, stacked nanosheet membranes can be formed by assembling nanosheets. The nanosheet membranes have stable structures in water and high separation performance against aniomic dyes and salts, suggesting high potential as separation membranes.
\end{abstract}

\section{Keywords}

Metal oxide nanosheet, Bottom-up approach, Surfactant, Photocatalyst, Acid site, Separation membrane

\section{Introduction}

Nanostructure catalysts have been extensively studied for applications in petrochemical production, removal of pollutants, and synthesis of alternative energy resources. Consequently, the development of catalysts with high functionality and environment-friendly synthesis processes are highly desirable. Recently, twodimensional (2D) nanomaterials, such as graphenebased materials (graphene, graphene oxide (GO) as well as reduced GO $)^{1}$, exfoliated nanosheets of metal oxide $^{2), 3)}$, transition metal dichalcogenides (TMDs) such as $\mathrm{MoS}_{2}{ }^{4), 5)}$, zeolites ${ }^{6)}$ and metal-organic framework $(\mathrm{MOF})^{7)}$ nanosheets have attracted increasing attention due to their high specific surface areas and unique physical and chemical properties that are typically unavailable in the bulk forms. In particular, metal oxide nanosheets offer important features such as defined and controllable protonic acidity and favorable electron-transfer characteristics. Therefore, applica-

DOI: doi.org/10.1627/jpi.62.53

*E-mail: knakagaw@ port.kobe-u.ac.jp tions such as solid-acid catalysts ${ }^{8) \sim 11)}$ and photocatalysts $^{12) \sim 17)}$ have been widely investigated.

The most common synthesis method to obtain 2D metal oxide nanosheets is the "exfoliation method" from the corresponding bulk layered oxide by the topdown approach (Fig. 1). Typically, multi-layered bulk compounds can be exfoliated by intercalating the layers with base molecules, followed by rupturing these multi-

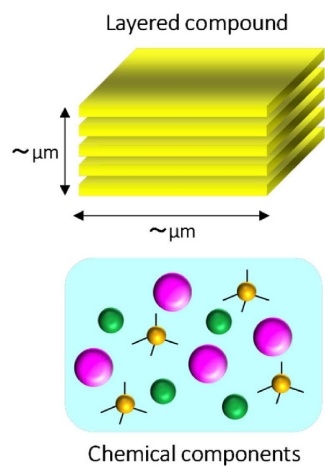

\section{Top-down approach:}

Exfoliation process using mechanical chemical and electrochemical methods

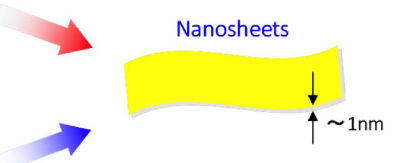

Bottom-up approach:

Synthesis process in liquid phase and gas phase

Fig. 1 Synthesis Methods of Two-dimensional Nanosheets by the Top-down Approach and Bottom-up Approach 
layered structures to obtain unilaminar colloids. However, fragmentation and re-aggregation of nanosheets pose challenges. The prepared colloidal molecular sheets in solution are highly unstable and readily undergo self-restacking and precipitation if the ionic strength or $\mathrm{pH}$ value of the solution is slightly changed. This technique also requires a long and cumbersome preparative procedure with successive acid-base treatments, to yield only a small quantity of nanosheets.

Therefore, we have developed a new bottom-up approach using a method based on controlled hydrolysis and condensation of metal alkoxides as a substrate molecule to produce a single molecular layer of metal oxide in solution by the hydrothermal method using surfactant as the template or adsorbing-chelating ligand. We describe our recent progress in the development of titanate nanosheets and niobate nanosheets synthesized by our bottom-up approach. Applications of these metal oxide nanosheets to photocatalysts and separation membranes are summarized.

\section{Layered Titanate Nanosheets}

\section{1. Synthesis}

Synthesis of metal oxide nanosheets was previously achieved by the formation of ordered mesostructures at the liquid-liquid interface between a mixed aqueous solution of surfactant and metal alkoxide, and water. Layered germanium oxide nanosheets were for the first time synthesized by hydrolysis and condensation reactions of germanium alkoxide using a flat thin water layer in the lamellar phase at the liquid-liquid interface forming a $2 \mathrm{D}$ confined reaction field ${ }^{18}$. This synthesis method for nanosheets using a lamellar template can produce metal oxide nanosheets over shorter times and at lower reaction temperatures compared to the conventional preparation process for metal oxide nanosheets. Therefore, this method is promising to obtain various types of metal oxide nanosheets. We applied this method to the synthesis of titanate nanosheets as follows.

Layered titanate nanosheets ${ }^{19)}$ 21) were synthesized by the hydrothermal method at $413 \mathrm{~K}$ for $96 \mathrm{~h}$, using tetraisopropylorthotitanate (TIPT) as a titanium source and two different amine surfactants, 1,12-dodecanediamine (DDA) as a template and triethanolamine (TEOA) as a chemical modifier. The products are named using the combination of precursors, such as Ti + DDA + TEOA, Ti + DDA and Ti + TEOA, respectively. X-ray diffraction (XRD) identified two peaks at $2 \theta=48.1^{\circ}$ and $62.7^{\circ}$ which correspond to the $2 \mathrm{D}$ reflections and 20 and 02 diffraction bands from the intrananosheet periodicity of $0.38 \times 0.30 \mathrm{~nm}$ for lepidocrocite titanate ${ }^{22 \sim 24)}$ observed for Ti + DDA + TEOA (Fig. 2) ${ }^{20)}$, whereas the $\mathrm{TiO}_{2}$ anatase phase (JCPDS file

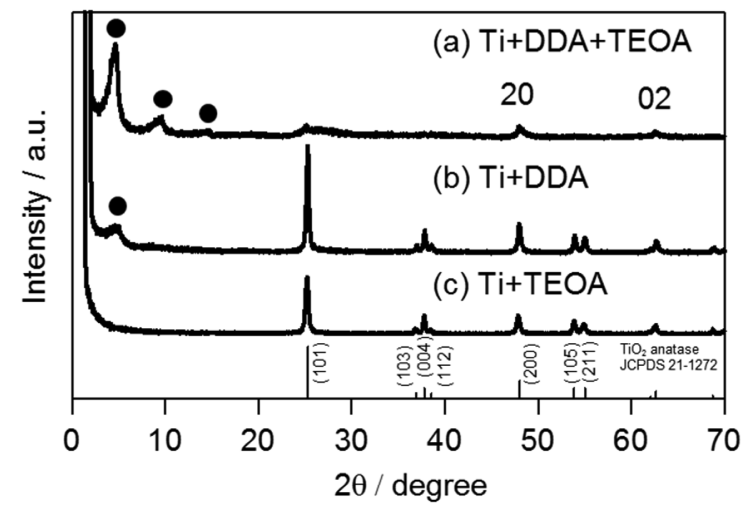

Fig. 2 XRD Patterns of (a) Ti + DDA + TEOA, (b) Ti + DDA and (c) $\mathrm{Ti}+\mathrm{TEOA}$

[Reprinted with permission from Ref. 20). Copyright (2012) WileyVCH.]

no. 21-1272) was mainly observed for Ti + DDA and Ti + TEOA. Furthermore, considerable differences were found in the mesostructures and crystal structures of $\mathrm{Ti}$ + DDA + TEOA formed by hydrothermal synthesis at different $\mathrm{pH} . \quad \mathrm{TiO}_{2}$ anatase phase was observed using $\mathrm{pH}$ of 8.0. In contrast, lepidocrocite titanate was observed using $\mathrm{pH}$ from 10.0 to 12.8 . In addition, three peaks at $2 \theta=4.6-4.7,9.2-9.4$ and $13.9-14.2^{\circ}$ were observed for $\mathrm{Ti}+\mathrm{DDA}+\mathrm{TEOA}$ prepared using $\mathrm{pH}$ from 10.0 to 11.0. These peaks indicated the formation of a highly ordered lamellar mesostructure with an interlayer spacing of about $1.9 \mathrm{~nm}$. Scanning electron microscope (SEM) and transmission electron microscope (TEM) observed sheet-like morphology with multilayer structures in $\mathrm{Ti}+\mathrm{DDA}+\mathrm{TEOA}\left(\mathbf{F i g}\right.$. 3) ${ }^{20)}$. The interlayer spacing of these layered structures was estimated to be $1.0-1.5 \mathrm{~nm}$ from high-resolution TEM images, and the selected area electron diffraction (SAED) patterns were consisted of a series of diffraction rings derived from the lepidocrocite titanate ${ }^{20)}$.

\section{2. Formation Mechanism}

Layered titanate nanosheets with lamellar mesostructure were formed through the hydrolysis and condensation of TEOA-modified TIPT. The potential for 2D anisotropic growth of titanium oxide to form the lamellar mesostructure in this method arises from the DDA self-assembly and the nature of the titanate crystal structure. Ordered lamellar mesostructure was found to form at the liquid-liquid interface using amine surfactants such as laurylamine and DDA in contact with water ${ }^{18)}$. Therefore, hydrolysis and condensation are expected to occur in the 2D water layer in the lamellar phase. On the other hand, the crystal structure requires a $2 \mathrm{D}$ sheet structure of anionic $\mathrm{TiO}_{6}$ framework to contain cations in a layered titanate structure. The positive charged DDA molecules act as cations if the $\mathrm{pH}$ is adjusted to 10.0-11.0. Previous studies using Time-of-Flight Secondary Ion Mass Spectrometry 

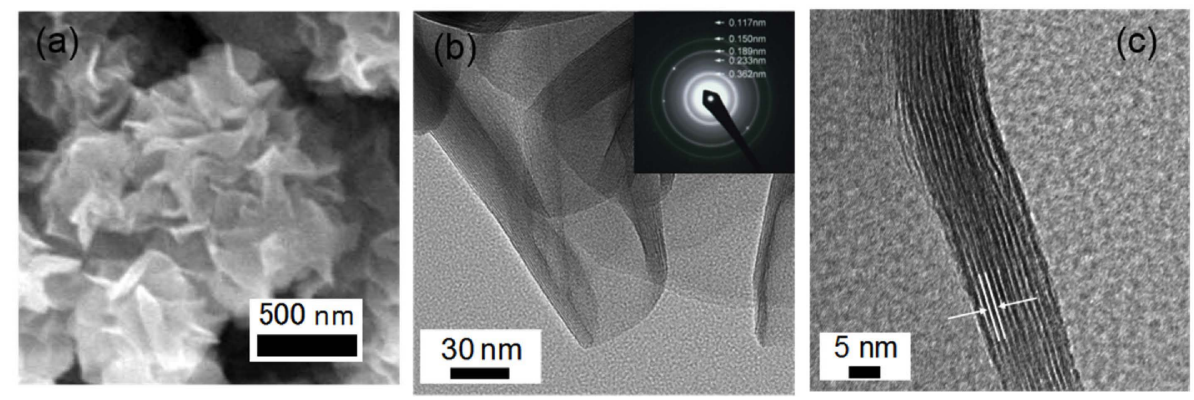

Fig. 3 (a) SEM, (b) TEM and (c) High-resolution TEM Images of Ti + DDA + TEOA (inset in (b): SAED pattern)

[Reprinted with permission from Ref. 20). Copyright (2012) Wiley-VCH.]

(a) Template of lamellar self-assembly

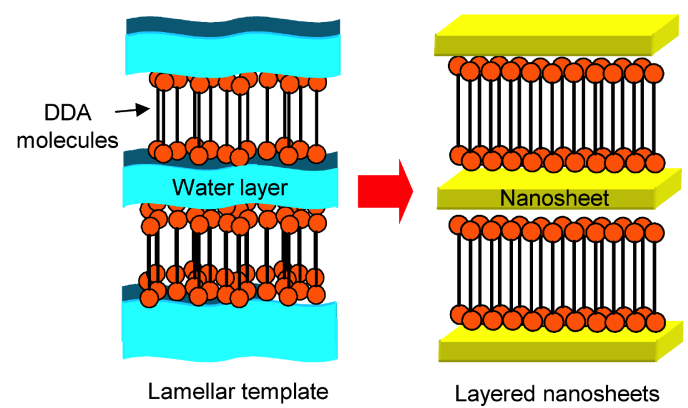

(b) Electrostatic interactions

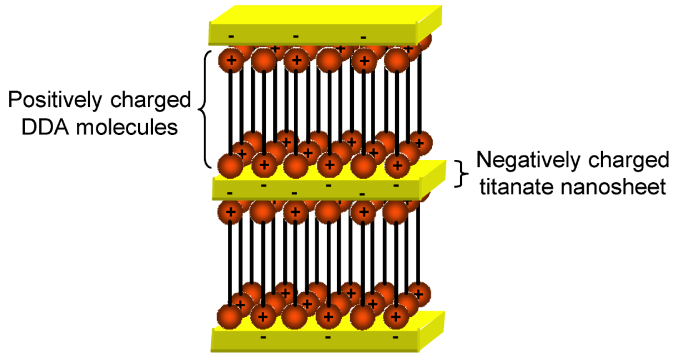

Fig. 4 Formation Mechanism of Titanate Nanosheets: (a) lamellar self-assembly on a template and (b) electrostatic interaction between negatively charged titanate nanosheets and positively charged amine surfactants

[Reprinted with permission from Ref. 20). Copyright (2012) WileyVCH.]

(TOF-SIMS) analysis, Gentle Secondary Ion Mass Spectrometry Gentle-SIMS (G-SIMS), and g-ogram methods also showed that the DDA molecule in only $\mathrm{Ti}$ + DDA + TEOA sample was not easily fragmented, implying the formation of robust hydrophobic domains with lamellar mesostructure ${ }^{25), 26)}$. Thus, the proposed formation mechanism of layered titanate nanosheets is shown in Fig. $4^{20)}$. The layered titanate nanosheets were synthesized using a lamellar phase of DDA acting as a self-assembly template (Fig. 4(a)). Selfassembly of the nanosheets and DDA molecules occurred based on the electrostatic interactions
(Fig. 4(b)).

2.3. Surface Modification and Photocatalytic Degradation

The advantage of this nanosheet synthesis method is the effective surface modification of nanosheets because the surfactant molecules cover the entire surface of the nanosheets. In addition, the chemical interactions between the nanosheets and surfactant molecules through the nanosheet synthetic process can be improved. The effects of the lamellar mesostructure on the optical, adsorption and photocatalytic properties of layered titanate nanosheets were investigated.

Layered titanate nanosheets with or without lamellar mesostructure were compared. Both layered titanate nanosheets absorbed light in the visible region. In particular, Ti + DDA + TEOA with a lamellar mesostructure exhibited a larger wavelength shift for the absorption edge in the visible region than $\mathrm{Ti}+\mathrm{DDA}+\mathrm{TEOA}$ without a lamellar mesostructure. Presumably amine compounds facilitated $\mathrm{Ti}^{-} \mathrm{N}$ charge transfer during the hydrothermal processes, which would promote nitrogen doping. Consequently, Ti + DDA + TEOA with a lamellar mesostructure in which DDA molecules cover the entire surface of the nanosheets absorbed visible light more strongly than Ti + DDA + TEOA without a lamellar mesostructure ${ }^{20)}$.

The photocatalytic activity of the layered titanate nanosheets for degradation of Rhodamine $\mathrm{B}(\mathrm{RhB})$ under irradiation with visible light $(\lambda=470 \mathrm{~nm})$ was evaluated. Ti + DDA + TEOA with a lamellar mesostructure (BET specific surface area, $S_{\text {BET }} 78 \mathrm{~m}^{2} \mathrm{~g}^{-1}$ ) adsorbed more RhB in the dark than Ti + DDA + TEOA without a lamellar mesostructure $\left(S_{\mathrm{BET}}: 175 \mathrm{~m}^{2} \mathrm{~g}^{-1}\right)$ according to the initial decrease in the concentration of $\mathrm{RhB}$ before irradiation. Presumably the RhB molecules were adsorbed into the lamellar mesostructure through cation exchange between $\mathrm{RhB}$ and cationic DDA molecules because the interlayer spacing of the lamellar mesostructure was large enough to adsorb $\mathrm{RhB}$ molecules. Consequently, Ti + DDA + TEOA with a lamellar mesostructure showed higher photocatalytic 

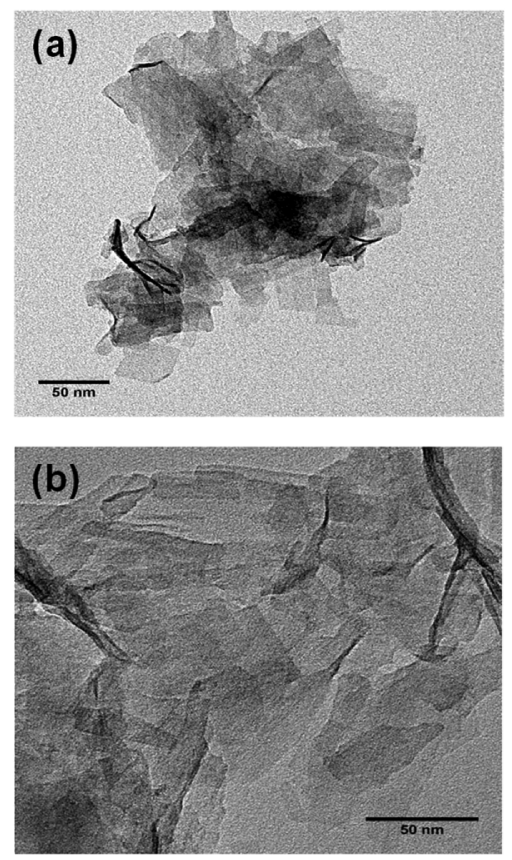

Fig. 5 (a, b) TEM Images of Discrete Single Molecular Sheets of Niobate

[Reprinted with permission from Ref. 27). Copyright (2014) The Royal Society of Chemistry.]

activity than $\mathrm{Ti}+\mathrm{DDA}+\mathrm{TEOA}$ without a lamellar mesostructure $^{21)}$. The photocatalytic activity of the layered titanate nanosheets is strongly related to their light absorption and adsorption properties. This property shows the potential for the development of selective molecular reactions utilizing control of the interlayer spacing of the lamellar mesostructure and hydrophobicity of the surfactant layer.

\section{Single Layer Niobate Nanosheets}

\section{1. Synthesis}

Single molecular layers of niobate ${ }^{27)}$ were synthesized using the hydrothermal method with niobium(V) ethoxide $\left(\mathrm{Nb}(\mathrm{OEt})_{5}\right)$ as niobium source in ammonium aqueous solution in the presence of TEOA, which is the same chemical modifier for the synthesis of layered titanate nanosheets. Distinct flat single molecular layer sheets with sharp edges were observed (Fig. 5). XRD showed severe broadening or near absence of the (020) peak, implying extremely ultrathin layered structures. In contrast, TEM demonstrated a rolled or scrolled molecular sheet morphology with stacking of the sheets (4-20 layers) obtained by synthesis without TEOA.

The single molecular layers of niobate form through similar hydrolysis and condensation processes to TEOA-modified $\mathrm{Nb}(\mathrm{OEt})_{5}$. To control formation of the niobium oxide 2D structure and morphology under solution-like homogeneous conditions, TEOA is utilized as an adsorbing-chelating ligand ${ }^{20)}$ to stabilize
$\mathrm{Nb}(\mathrm{OEt})_{5}$ against rapid hydrolysis in the alkaline $\mathrm{pH}$ range. As a result, anionic niobate consisting of $\mathrm{NbO}_{6}$ octahedral framework was formed with excess $\mathrm{OH}^{-}$ under basic conditions and $\mathrm{HNb}_{3} \mathrm{O}_{8}$ like molecular layers were produced. The presence of TEOA can slow both the hydrolysis and condensation of $\mathrm{Nb}(\mathrm{OEt})_{5}$ and reduce rapid crystal growth. Thus, TEOA would reduce the stacking of molecular layers into a 3D structure.

\section{2. Hydrogen Evolution from Water}

Photocatalytic hydrogen evolution from water splitting catalyzed by single molecular layers of niobate were evaluated in water under UV lamp excitation (280-320 nm, 500 W) using methanol as a sacrificial reagent. Niobate molecular sheets achieved higher hydrogen evolution rate $\left(6.1 \mu \mathrm{mol} \mathrm{h} \mathrm{h}^{-1}\right)$ compared with commercial Degussa P-25 (standard $\mathrm{TiO}_{2}$ sample; $0.8 \mu \mathrm{mol} \mathrm{h}^{-1}$ ), $\mathrm{Nb}_{2} \mathrm{O}_{5}$ (Johnson Matthey; inert) and layered niobium oxide $\left(1.5 \mu \mathrm{mol} \mathrm{h} \mathrm{h}^{-1}\right)^{27)}$. The improved photocatalysis of the $2 \mathrm{D}$ structures with reduced thickness compared to the bulk forms is probably due to a combination of several factors. The higher surface to volume ratio of thinner layers would favor higher activity. In addition, the electrons and holes produced from the bulk structure would have to diffuse to the surface for photocatalysis. Long diffusion paths and recombination over structural defects would also be key factors.

To enhance the lifetime of the charge carriers for redox reactions, coating or depositing with other semiconductors to form heterojunction structures for fast charge separation would prolong the lifetime of the excitons, resulting in improved hydrogen productivity 28$) \sim 31$ ). Thus, the single molecular layers of niobate (hy-NbTEOA) prepared by the hydrothermal method were added to graphene oxide (GO) or $\mathrm{MoS}_{2}$ which have similarly layered structures and can also be dispersed in solution to enable close contact with the niobate sheets with different potential energies, by simple physical mixing in the powder forms before re-dispersion. Control GO and $\mathrm{MoS}_{2}$ samples were found to be inert for photocatalytic hydrogen production. However, dramatic improvement in photocatalytic hydrogen production activity was clearly observed with mixed GO and $\mathrm{MoS}_{2}{ }^{27)}$. The measured hydrogen evolution rate for hy-Nb-TEOA $+\mathrm{GO}+\mathrm{MoS}_{2}\left(\mathrm{GO}: 0.5 \mathrm{wt} \%, \mathrm{MoS}_{2}\right.$ : $0.5 \mathrm{wt} \%$ ) was around seven times higher than that of hy-Nb-TEOA (Fig. 6). 2D niobate molecular sheets should absorb light and generate excited electrons and holes under UV irradiation. As the holes are scavenged by a sacrificial reagent, rapid electron transfer from niobate nanosheets to $\mathrm{MoS}_{2}$ through GO will reduce the recombination rate of electron-hole pairs in the niobate sheets and facilitate catalytic hydrogen production on the edge sites of $\mathrm{MoS}_{2}$ through the fast photoelectron excitation between the hetero-structures (Fig. 7). Therefore, such promising 2D materials should be positioned in very close proximity to the sin- 


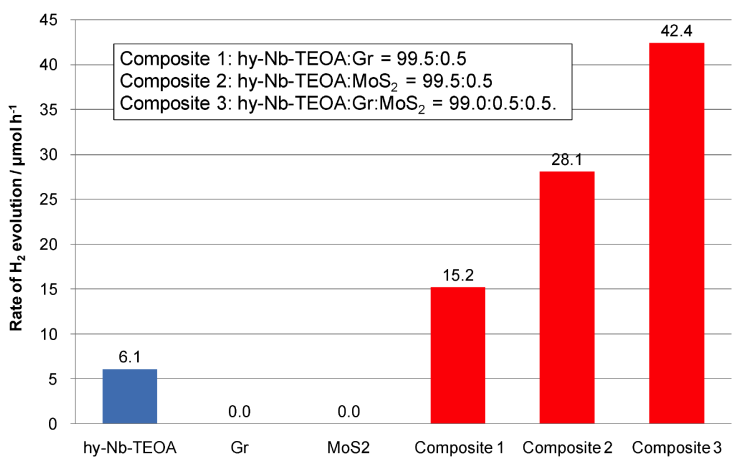

Fig. 6 Adding Graphene Oxide and $\mathrm{MoS}_{2}$ to hy-Nb-TEOA by Physical Mixing for Improved Photocatalytic Hydrogen Evolution Rates

[Reprinted with permission from Ref. 27). Copyright (2014) The Royal Society of Chemistry.]

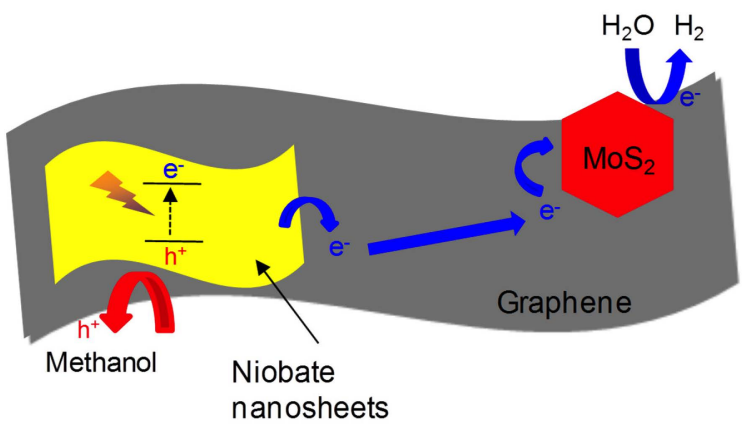

Fig. 7 Schematic Diagram of the Proposed Mechanism for Photocatalytic Activity of Hydrogen Production over Single Molecular Layer Niobate Sheets + Graphene Oxide $+\mathrm{MoS}_{2}$ Ensemble System under UV Irradiation

[Reprinted with permission from Ref. 27). Copyright (2014) The Royal Society of Chemistry.]

gle molecular layers of niobate without blocking their catalytically active sites.

\section{Nanosheet Membranes}

The ideal separation membrane for the treatment of water includes the thinnest separation layers possible to maximize permeation flux, and pore structure with appropriate sizes to ensure superior rejection performance. Design of new types of inorganic membranes with advanced structures is necessary for achievement of these goals. 2D nanosheet membranes including porous nanosheet membranes ${ }^{7), 32), 33)}$, stacked nanosheet membranes ${ }^{34) \sim 36)}$, and nanosheet composite membranes $^{37)}$ have recently opened up new possibilities for fabricating separation membranes. Stacked nanosheet membranes can be fabricated by assembling single layer nanosheets into ultrathin membranes, and will contain 2D channels between the stacked nanosheets that allow water molecules to pass through whilst rejecting sol- utes. Stacked nanosheet membranes also offer separation capability based on modifiable 2D channels. However, only a narrow range of nanosheet types, especially graphene based materials, have been studied for membrane fabrication.

\section{1. Fabrication}

Recently, stacked niobate nanosheet membranes (NbO membrane) were fabricated from 2D niobate nanosheets by simple vacuum filtration ${ }^{38)}$. Single molecular layers of niobate as described in section 3. were assembled by vacuum filtration on a cellulose nitrate (CN) support modified with 3-aminopropyl-triethoxysilane (APTES) (Fig. 8(a)). The cross-section image (Fig. 8(d)) shows the formation of ultrathin membrane with thickness of about $20 \mathrm{~nm}$ and all nanosheets appear to be interconnected and form a flat thin layer on the support. One outstanding characteristic of this membrane is its structural stability in water. The structural stability in water of stacked nanosheet membranes is one of the critical issue for applications, because $2 \mathrm{D}$ nanosheets carry a surface charge on hydration, which can cause the membrane to disintegrate via electrostatic repulsion, resulting in redispersion of the nanosheets ${ }^{39)}$. The structural differences between dry and wet conditions were investigated using XRD (Fig. 8(b)). Only a slight increase of the interlayer distance from 1.0 to $1.1 \mathrm{~nm}$ was observed for $\mathrm{NbO}$ membranes, whereas a drastic increase of the interlayer distance from 0.7 to $1.5 \mathrm{~nm}$ was observed for $\mathrm{GO}$ membranes (not shown). These results imply that the $\mathrm{NbO}$ membranes retain high structural stability in water.

Such structural stability would arise from the surface acidity of the $\mathrm{NbO}$ nanosheets. The correlations between structure and acidity for hydrated niobium oxides have been studied using various analytical techniques ${ }^{40), 41)}$. The structural changes in niobate nanosheets with few to single layer structures result from their high structural flexibility. Hydrated niobium oxides are very strong solid Brønsted acids (BAs), containing both terminal and bridging hydroxyls as BA sites. In addition, Lewis acid (LA) sites arise from lower coordinate $\mathrm{NbO}_{5}$ and in some cases $\mathrm{NbO}_{4}$ sites, which occur because of the formation of oxygen vacancies in thin and flexible $\mathrm{NbO}_{6}$ systems via the removal of two adjacent BA sites in the form of water and/or via breakage of elongated $\mathrm{Nb}---\mathrm{O}$ bonds in the parent $\mathrm{O}=$ $\mathrm{Nb}---\mathrm{O}$ structure during synthesis in the presence of surfactants (Fig. 9) ${ }^{41)}$. Therefore, the amino groups of APTES and TEOA reacted with these acid sites of niobate nanosheets via both coordination and hydrogen bonding during vacuum filtration and drying, resulting in stronger interactions between the nanosheets and support or nanosheet layers (Fig. 10) ${ }^{38)}$. Therefore, the APTES and TEOA molecules effectively crosslink the nanosheet layers and strengthen the final membrane. 

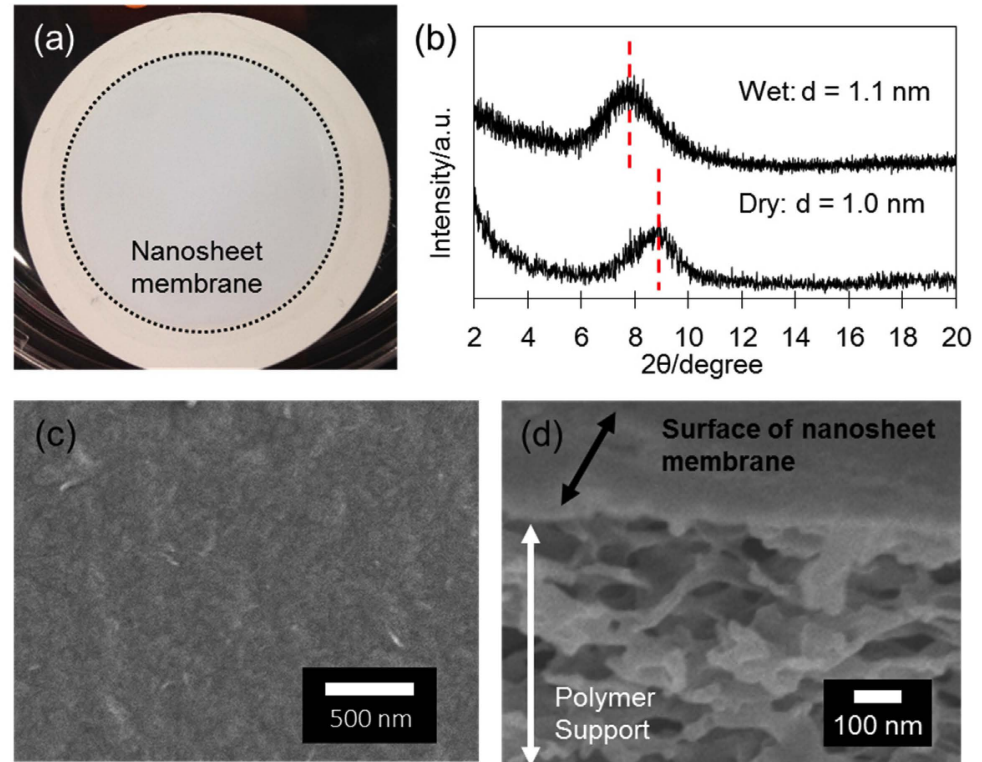

Fig. 8 (a) Photograph of NbO Membranes, (b) XRD Patterns of NbO Membranes under Dry and Wet Conditions, (c) Overview and (d) Cross-section FE-SEM Image of $\mathrm{NbO}$ Membrane $^{38)}$

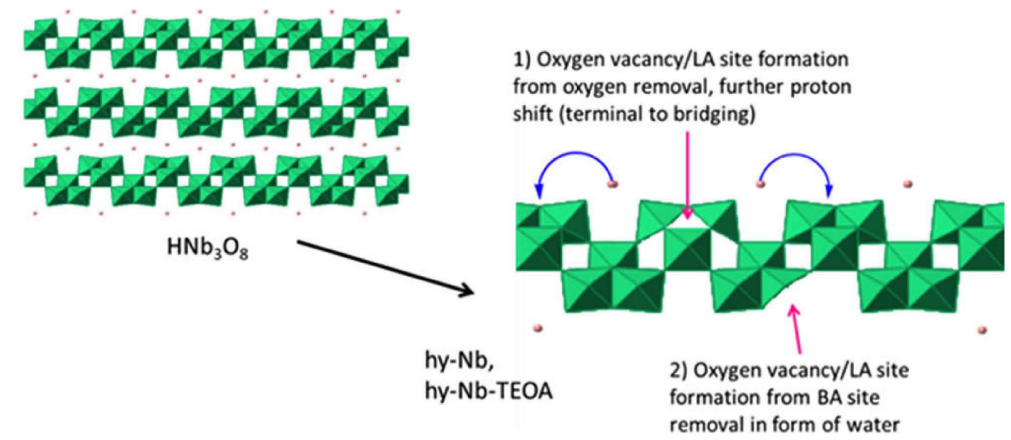

Fig. 9 Proposed Oxygen Vacancy/LA Site Formation by Downscaling from Bulk $\mathrm{HNb}_{3} \mathrm{O}_{8}$ to Few to Single Layer Niobate Nanosheets (hy-Nb and hy-Nb-TEOA) [Reprinted with permission from Ref. 41). Copyright (2017) American Chemical Society.]

\section{2. Separation Performance}

The molecular weight cutoffs (MWCOs; the $M w$ at which $90 \%$ rejection was achieved) of the membranes were measured using polyethylene glycol with a range of molecular weights. The MWCOs were $4.3 \mathrm{kDa}$ for $\mathrm{NbO}$ membranes with a thickness of $20 \mathrm{~nm}$. The Stokes-Einstein radii corresponding to these molecular weights can be estimated as $1.7 \mathrm{~nm}$. Considering that the thickness of a single $\mathrm{NbO}$ sheet is $0.9 \mathrm{~nm}^{27}$, the clearance gap between the sheet layers was calculated as only $0.2 \mathrm{~nm}$ under the wet condition. Therefore, formation of void structures is suggested in the stacked $\mathrm{NbO}$ membranes as water passes through the thin membranes during vacuum filtration. The channels are created with size dependent on the nanosheet thickness and numbers of layers. Consequently, different chan- nel structures are suggested compared with conventional stacked nanosheet membranes using 2D nanochannels between the stacked nanosheets.

The rejection characteristics of the $\mathrm{NbO}$ membranes were studied using anionic dyes and salts (Fig. 10 $)^{38)}$. Over $90 \%$ rejections were obtained for anionic dyes such as Evans blue (EB, Mw: 960.8) and Acid red 265 (Mw: 635.6). In addition, around $80 \%$ rejection was obtained for $\mathrm{Na}_{2} \mathrm{SO}_{4}$. These findings indicate that the $\mathrm{NbO}$ membrane acts as a nanofiltration (NF) membrane. The niobate nanosheets have negative surface charge derived from the 2D crystal structure, so these high separation performances were obtained because of the electrostatic repulsion (Donnan exclusion mechanism) between the membrane surfaces and anionic species. 

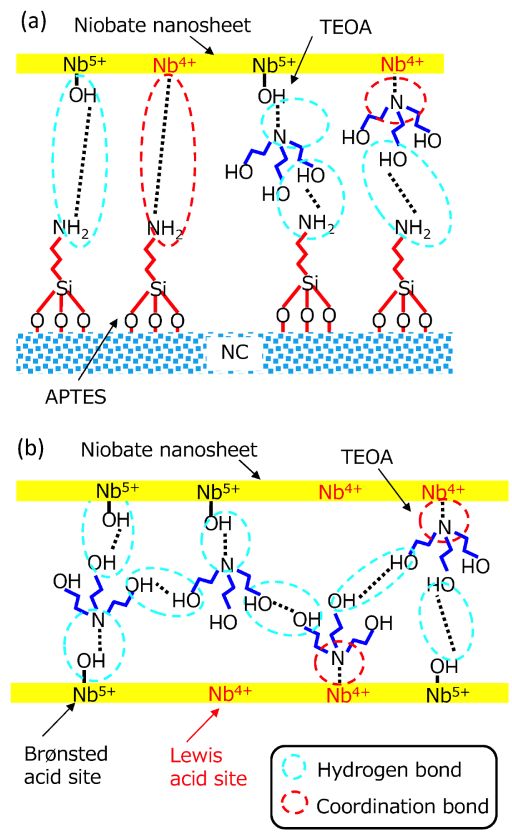

(a) Interactions between nanosheet and NC-APTES, (b) interactions between nanosheets.

Fig. 10 Schematic Diagrams of Possible Interfacial Interactions in $\mathrm{NbO}$ Membranes

[Reprinted with permission from Ref. 38). Copyright (2017) The Royal Society of Chemistry.]

\section{Conclusion}

The development of metal oxide nanosheets synthesized by the bottom-up approach for photocatalysts and separation membranes were reviewed. Layered titanate nanosheets with lamellar mesostructures were synthesized using a lamellar phase of DDA as a self-assembly template. In contrast, single molecular layers of niobate were synthesized in the presence of TEOA. These metal oxide nanosheets showed unique photocatalytic activities. In particular, niobate nanosheets and composites with GO and $\mathrm{MoS}_{2}$ showed high photocatalytic hydrogen production activity from water. Synthesis of other transition metal oxide nanosheets by this bottom-up method may discover high potential for catalytic properties. Single niobate nanosheet was utilized for the fabrication of stacked metal oxide nanosheet membranes for nanofiltration. Improvement of the fabrication method and investigation of other transition metal oxide nanosheets are desirable. The present findings indicate wider applications of functional membranes such as for catalytic membrane reactors.

\section{Acknowledgment}

This work was supported by JSPS KAKENHI Grant Numbers 25420827 and 16K06829, and Kurita Water and Environment Foundation Grant Number 16A078.
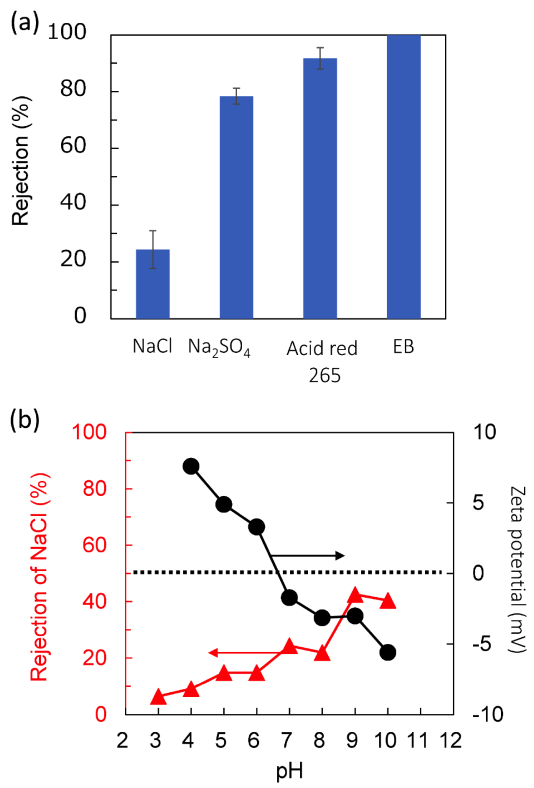

Fig. 11 (a) Rejection Characteristics of Each Salt for NbO Membranes $(20 \mathrm{~nm})$, (b) Rejection of $\mathrm{NaCl}$ and Zeta Potential as Function of pH for NbO Membranes (20 nm)

[Reprinted with permission from Ref. 38). Copyright (2017) The Royal Society of Chemistry.]

I express my thanks to Prof. Motonari Adachi of Kyoto University (Fuji Chemical Co., Ltd. at present), Prof. Shigeru Sugiyama of Tokushima University, Prof. Shik Chi Edman Tsang of The University of Oxford, and Prof. Hideto Matsuyama and Prof. Tomohisa Yoshioka of Kobe University for their kind and valuable support.

\section{References}

1) Perreault, F., Fonseca de Faria, A., Elimelech, M., Chem. Soc. Rev., 44, (16), 5861 (2015).

2) Schaak, R., Mallouk, T. E., Chem. Mater, 12, 2513 (2000).

3) Sasaki, T., Nakano, S., Yamauchi, S., Watanabe, M., Chem. Mater, 9, 602 (1997).

4) Liu, G., Robertson, A. W., Li, M. M.-J., Kuo, W. C. H., Darby, M. T., Muhieddine, M. H., Lin, Y.-C., Suenaga, K., Stamatakis, M., Warner, J. H., Tsang, S. C. E., Nat. Chem., 9, (8), 810 (2017).

5) Wang, Z., Mi, B., Environ. Sci. Technol., 51, (15), 8229 (2017).

6) Choi, M., Na, K., Kim, J., Sakamoto, Y., Terasaki, O., Ryoo, R., Nature, 461, (7261), 246 (2009).

7) Peng, Y., Li, Y., Ban, Y., Jin, H., Jiao, W., Liu, X., Yang, W., Science, 346, (6215), 1356 (2014).

8) Takagaki, A., Sugisawa, M., Lu, D., Kondo, J. N., Hara, M., Domen, K., Hayashi, S., J. Am. Chem. Soc., 125, 5479 (2003).

9) Takagaki, A., Lu, D., Kondo, J. N., Hara, M., Hayashi, S., Domen, K., Chem. Mater., 17, 2487 (2005).

10) Dias, A., Lima, S., Carriazo, D., Rives, V., Pillinger, M., Valente, A. A., J. Catal., 244, 230 (2006).

11) Zhao, Y., Zhou, X., Ye, L., Tsang, S. C. E., Nano Rev., 3, 17631 (2012).

12) Kudo, A., Tanaka, A., Domen, K., Maruya, K., Aika, K., Onishi, T., J. Catal., 111, 67 (1988).

13) Abe, R., Shinohara, K., Tanaka, A., Hara, M., Kondo, J. N., 
Domen, K., Chem. Mater, 9, 2179 (1997).

14) Ebina, Y., Sasaki, T., Harada, M., Watanabe, M., Chem. Mater., 14, 4390 (2002).

15) Compton, O., Carroll, E., Kim, J. Y., Larsen, D. S., Osterloh, F. E., J. Phys. Chem. C, 111, 14589 (2007).

16) Maeda, K., Mallouk, T. E., J. Mater. Chem., 19, 4813 (2009).

17) Okamoto, Y., Ida, S., Hyodo, J., Hagiwara, H., Ishihara, T., J. Am. Chem. Soc., 133, (45), 18034 (2011).

18) Adachi, M., Nakagawa, K., Sago, K., Murata, Y., Nishikawa, Y., Chem. Commun., 2381 (2005).

19) Nakagawa, K., Yamaguchi, K., Yamada, K., Ogata, T., Sotowa, K.-I., Sugiyama, S., Adachi, M., Chem. Lett., 40, (7), 687 (2011).

20) Nakagawa, K., Yamaguchi, K., Yamada, K., Sotowa, K.-I., Sugiyama, S., Adachi, M., Eur. J. Inorg. Chem., 2012, 2741 (2012).

21) Nakagawa, K., Ogata, T., Yamaguchi, K., Jitoku, J., Sotowa, K.-I., Sugiyama, S., Moriga, T., Adachi, M., Sci. Adv. Mater., 6, (7), 1535 (2014).

22) Sasaki, T., Ebina, Y., Kitami, Y., Watanabe, M., Oikawa, T., J. Phys. Chem. B, 105, (26), 6116 (2001).

23) Wang, F., Jiu, J., Pei, L., Nakagawa, K., Isoda, S., Adachi, M., Chem. Lett., 34, (3), 418 (2005).

24) Wang, F., Jiu, J., Pei, L., Nakagawa, K., Isoda, S., Adachi, M., Chem. Lett., 34, (9), 1238 (2005).

25) Mihara, I., Nakagawa, K., Kudo, M., Aoyagi, S., Surf. Interface Anal., 45, (1), 453 (2013).

26) Mihara, I., Nakagawa, K., Kudo, M., Aoyagi, S., Surf. Interface Anal., 47, (7), 764 (2015).

27) Nakagawa, K., Jia, T., Zheng, W., Fairclough, S. M., Katoh, M., Sugiyama, S., Tsang, S. C. E., Chem. Commun., 50, (89), 13702 (2014)

28) Li, Q., Guo, B., Yu, J., Ran, J., Zhang, B., Yan, H., Gong, J. R., J. Am. Chem. Soc., 133, 10878 (2011).
29) Xiang, Q., Yu, J., Jaroniec, M., J. Am. Chem. Soc., 134, 6575 (2012).

30) Jia, T., Kolpin, A., Ma, C., Chan, R. C.-T., Kwok, W.-M., Tsang, S. C. E., Chem. Commun., 50, (10), 1185 (2014).

31) Jia, T., Li, M. M. J., Ye, L., Wiseman, S., Liu, G., Qu, J., Nakagawa, K., Tsang, S. C. E., Chem. Commun., 51, (70), 13496 (2015).

32) Varoon, K., Zhang, X., Elyassi, B., Brewer, D. D., Gettel, M., Kumar, S., Lee, J. A., Maheshwari, S., Mittal, A., Sung, C.-Y., Cococcioni, M., Francis, L. F., McCormick, A. V., Mkhoyan, K. A., Tsapatsis, M., Science, 334, (6052), 72 (2011).

33) Surwade, S. P., Smirnov, S. N., Vlassiouk, I. V., Unocic, R. R., Veith, G. M., Dai, S., Mahurin, S. M., Nat. Nanotechnol., 10, (5), 459 (2015).

34) Nair, R. R., Wu, H. A., Jayaram, P. N., Grigorieva, I. V., Geim, A. K., Science, 335, 442 (2012).

35) Huang, H., Song, Z., Wei, N., Shi, L., Mao, Y., Ying, Y., Sun, L., Xu, Z., Peng, X., Nat. Commun., 4, 2979 (2013).

36) Mi, B., Science, 343, (6172), 740 (2014).

37) Rodenas, T., Luz, I., Prieto, G., Seoane, B., Miro, H., Corma, A., Kapteijn, F., Llabrés i Xamena, F. X., Gascon, J., Nat. Mater., 14, (1), 48 (2015).

38) Nakagawa, K., Yamashita, H., Saeki, D., Yoshioka, T., Shintani, T., Kamio, E., Kreissl, H. T., Tsang, S. C. E., Sugiyama, S., Matsuyama, H., Chem. Commun., 53, (56), 7929 (2017).

39) Yeh, C.-N., Raidongia, K., Shao, J., Yang, Q.-H., Huang, J., Nat. Chem., 7, (2), 166 (2015).

40) Kreissl, H. T., Nakagawa, K., Peng, Y.-K., Koito, Y., Zheng, J., Tsang, S. C. E., J. Catal., 338, 329 (2016).

41) Kreiss1, H. T., Li, M. M. J., Peng, Y.-K., Nakagawa, K., Hooper, T. J. N., Hanna, J. V., Shepherd, A., Wu, T.-S., Soo, Y.L., Tsang, S. C. E., J. Am. Chem. Soc., 139, (36), 12670 (2017).

要旨

ボトムアップ法により合成される金属酸化物ナノシート一触媒および分離膜への応用一

中川 敬三

神戸大学大学院科学技術イノベーション研究科/先端膜工学センター, 657-8501 神戸市灘区六甲台町1-1

二次元金属酸化物ナノシートは，高比表面積や表面酸特性な どの特徵を有し，固体酸触媒や光触媒などの分野で注目を集め ている。ナノシートは一般にはトップダウン的な手法，いわゆ る層状化合物からの “剝離法”により得られるが，ナノシート の破砕や再凝集が起こるなどの欠点があり，また高温・長時間 の焼成や $2 \mathrm{D}$ 結晶層の剝離処理を必要とし，量産化のためには 簡易な合成手法の開発が望まれている。本研究では界面活性剤 を用い，金属アルコキシドの加水分解・重縮合反応によるボト ムアップ法により, 多層チタン酸ナノシートおよび単層ニオブ
酸ナノシートを開発した。本手法により得られる金属酸化物ナ ノシートの形成プロセスや, 界面活性剤による表面修飾効果を 明らかとした。また, 有機色素の光分解や水の光分解による水 素生成に応用し, ナノシート材料と異種 $2 \mathrm{D}$ ナノシート（酸化 グラフェンや $\mathrm{MoS}_{2}$ ) との複合化による効果的な触媒機能を発 現させた。さらに, これらナノシートを積層することにより得 られる積層型ナノシート膜が, 水中で安定かつアニオン性色素 や塩に対して高い分離機能を有し, 分離膜として機能すること を見出した。 